\title{
Can north american fish passage tools work for South american migratory fishes?
}

\author{
Claudio Rafael Mariano Baigún*, John Michael Nestler**, Norberto Oscar Oldani***, \\ R. Andrew Goodwin** and Larry J. Weber****
}

In North America, the Numerical Fish Surrogate (NFS) is used to design fish bypass systems for emigrating juvenile salmon as they migrate from hatchery outfalls and rearing habitats to adult habitat in the oceans. The NFS is constructed of three linked modules: 1) a computational fluid dynamics model describes the complex flow fields upstream of dams at a scale sufficiently resolved to analyze, understand and forecast fish movement, 2) a particle tracking model interpolates hydraulic information from the fixed nodes of the computational fluid model mesh to multiple locations relevant to migrating fish, and 3) a behavior model simulates the cognition and behavior of individual fish in response to the fluid dynamics predicted by the computational fluid dynamics model. These three modules together create a virtual reality where virtual fish exhibit realistic dam approach behaviors and can be counted at dam exits in ways similar to the real world. Once calibrated and validated with measured fish movement and passage data, the NFS can accurately predict fish passage proportions with sufficient precision to allow engineers to select one optimum alternative from among many competing structural or operational bypass alternatives. Although South American fish species are different from North American species, it is likely that the basic computational architecture and numerical methods of the NFS can be used for fish conservation in South America. Consequently, the extensive investment made in the creation of the NFS need not be duplicated in South America. However, its use in South America will require that the behavioral response of the continent's unique fishes to hydrodynamic cues must be described, codified and tested before the NFS can be used to conserve fishes by helping design efficient South American bypass systems. To this end, we identify studies that could be used to describe the movement behavior of South American fishes of sufficient detail that they could be used to develop, calibrate and validate a South American version of the NFS.

Na América do Norte, o Numerical Fish Surrogate (NFS) é utilizado no projeto de sistemas de transposição de juvenis de salmão em seus deslocamentos dos habitats de desova e desenvolvimento inicial para o de adultos, no oceano. O NFS é estruturado em três módulos interconectados: 1) um modelo computacional de dinâmica de fluidos (CFD) que descreve o complexo escoamento acima da barragem em uma escala suficientemente apropriada para analisar, entender e prever os movimentos dos peixes, 2) um modelo de rastreamento de partículas que interpola informações hidráulicas dos nós da malha do modelo computacional para localizações múltiplas relevantes ao peixe em migração, 3) um modelo comportamental que simula o conhecimento e o comportamento de cada peixe em resposta à dinâmica do escoamento predita pelo modelo computacional. Esses três módulos juntos criam uma realidade virtual onde peixes virtuais exibem um comportamento realístico de aproximação da barragem e podem ser contados de uma forma similar a do mundo real. Uma vez calibrado e validado com medições do movimento dos peixes e dados de passagem, o NFS pode predizer acuradamente a proporção de passagem de peixes, com suficiente precisão para permitir que engenheiros selecionem uma alternativa ótima dentre as várias opções estruturais e operacionais. Embora as espécies de peixes Sul Americanas sejam diferentes das espécies da América do Norte, é provável que a arquitetura computacional básica e os métodos numéricos do NFS possam ser usados para a conservação de peixes na América do Sul. Consequentemente, o grande investimento feito na criação do NFS não precisa ser repetido na América do Sul. Contudo, seu uso na América do Sul exigirá que a resposta comportamental dessa fauna aos sinais hidrodinâmicos seja descrita, codificada e testada antes que o NFS possa ser usado na conservação de peixes pelo seu emprego na projeção de sistemas de transposição eficientes. Nesse contexto, o presente trabalho identifica estudos que poderiam ser utilizados para descrever o comportamento migratório de peixes da América do Sul com um nível de detalhamento suficiente para que possa ser utilizado no desenvolvimento, calibração e validação de uma versão sul-americana do NFS.

Key words: Hydraulic strain, Hydrodynamics, Numerical Fish Surrogate, Eulerian-Lagrangian-agent method.

\footnotetext{
*IIB-INTECH, Camino de Circunvalación Laguna, Km 6 (7120) Chascomus, Argentina. claudiobaigún@intech.gov.ar

**US Army Engineer Research and Development Center, Vicksburg, Mississippi, USA. john.m.nestler@erdc.usace.army.mil, rag12@cornell.edu

***Instituto de Desarrollo Tecnológico para la Industria Química, Güemes 3450 (3000) Santa Fe, Argentina. gbio@ceride.gov.ar

****IIHR - Hydroscience and Engineering, University of Iowa, Iowa City, Iowa, USA. larry-weber@uiowa.edu
} 


\section{Introduction}

Fragmentation by dams throughout the world has been linked to the loss of populations and species of fish. Successful passage designs reduce effects of dams or other barriers that obstruct the dispersal and migration of organisms. In the Pacific Northwest of the USA, downstream passage of out-migrating juvenile salmon (emigrants) around hydropower dams has historically been difficult to manage (Coutant \& Whitney, 2000). Improvements to bypass design depend on a better understanding of hydrodynamic cues used by emigrants to guide fine-scale swim path selection. However, most attempts to develop simple bypass design criteria typically focus on the behavior of emigrants near dams. Using this approach, even after decades of study, few generalizations can be made about the behaviors of emigrants near dams. We use three guiding principles to forge a new path to understand and explain fish movement behavior:

a) Fish migration behavior is related to the hydro-geomorphology of free-flowing rivers. Fish migration behavior evolved over long periods of time in the flow fields of natural, free-running rivers and not at geologically recent dams. The key to good hydraulic design criteria for bypass systems is in understanding the interrelationship between fluvial geomorphology and resultant flow pattern that must constitute the basis of swim path selection behavior.

b) The capabilities of the fish sensory system point to the hydrodynamic cues used by emigrants. Hydrodynamic cues used to navigate complex flow fields must be acquired by the fish mechanosensory system (used to detect acoustic and hydrodynamic stimuli).

c) Design criteria for bypass systems must recognize the behavioral complexity of fish. Design criteria based on means of simple hydraulic variables cannot capture the behavioral repertoire of animals evolved to move in spatially and temporally complex aquatic environments.

The key to good bypass design is to understand and forecast the response of an individual fish to the sequence of hydraulic conditions it encounters as it approaches the dam (Anderson, 1988). To this end, we describe a 'plug-and-play' simulation tool that integrates spatial/cognitive ecology, particle-tracking, and computational fluid dynamics (CFD) modeling to realistically and accurately forecast the volitional movement of emigrants in response to alternative designs of bypasses, guidance structures or project operations. The tool, the Numerical Fish Surrogate (NFS), is an individual-based model (IBM) using the Eulerian-Lagrangian-agent method (ELAM) that couples (1) a Eulerian framework governing the physical, hydrodynamic, and water quality domains, (2) a Lagrangian framework governing the sensory perception and movement trajectories of individual fish, and (3) an agent framework governing the cognitive domain responsible for behavior decisions and acclimatization of individuals (Goodwin et al., 2006). The NFS mechanistically forecasts small-scale (submeter to meter) individual movements of large numbers of virtual emigrants in response to flow field cues and can be used as an engineering design tool to forecast the performance of different bypass strategies and technologies.

In this paper, we briefly describe the components of the NFS to illustrate how the software works with the important proviso that much of the computational architecture and numerical methods (but not the behavioral component) developed for juvenile salmon will work for other species, either in North America or South America. We highlight those elements of the NSF that should apply to South American fish with little or no modification, consider the main differences between South and North American migratory fish species, and describe the kinds of studies that will need to be performed to apply the NFS to South American bypass design challenges.

\section{Methods}

\section{Conceptual framework and use of NFS}

Quantitative knowledge about emigrant movement is encoded as movement algorithms within the NFS. The NFS is run on the highly resolved output of a computational fluid dynamics (CFD) model that simulates the flow field associated with a design or operational alternative. The NFS then simulates individual fish movements through the virtual world of the CFD model and, similar to the real world, records their individual passage through the virtual outlets in the model. The NFS can be used in hindcast mode to develop and test algorithms that relate fish movement to flow field attributes if accurate, detailed and coincident data on 3-D fish position and hydraulic data are available. The NFS assumes that fish behavior is based on hydrodynamic cues only, although it is well known that a number of different cues (odor, light intensity and social interactions among emigrants) may also influence emigrant behavior. However, successful model validation using only hydrodynamic cues indicates that hydrodynamic cues dominate near dams (Goodwin et al., 2006). Additional cues can be easily included into the NFS if their spatial distribution can be described.

\section{How and why emigrants respond to hydraulic pattern}

All fish can perceive flow strength and direction (Montgomery et al., 2000; Voigt et al., 2000), whole body acceleration (Kalmijn, 1989), and spatial velocity gradients (Hudspeth, 1989) using a mechanosensory system, whether they exist in North or South America. In addition, emigrants are sensitive to pressure (Coutant, 2001) as are other species that possess a swim bladder. Fish sensory perception is integrated with a basic concept from fluvial geomorphology that flow resistance creates flow pattern to produce a "fish traffic rule" we named as the Strain-Velocity-Pressure (SVP) Hypothesis. The hypothesis is so named because it requires three hydrodynamic cues - a measure of flow field distortion (total hydraulic strain), velocity magnitude and hydrostatic pressure. The definitions of velocity magnitude and hydrostatic pressure are straightforward and can be found in any elementary text on open channel flow. 
We describe total flow field distortion using a metric called 'total hydraulic strain' because it integrates the fluid distortion mechanisms of (1) linear deformation (whose tensor metric components are normal strain rates), (2) rotation (whose tensor metric components are angular velocities), and (3) angular deformation (whose tensor metric components are onehalf the true shearing strain rates). We separate flow resistance into two categories for sub-critical, steady flow: friction resistance and form resistance. Friction resistance in a simple, straight, uniform channel produces a flow pattern in which average velocities are lowest nearest a source of friction (such as the channel bottom and edges) with a zero water velocity occurring at the water-channel interface. Pattern in the total hydraulic strain field is the inverse of pattern in the velocity field, with lowest total hydraulic strain occurring furthest from sources of friction resistance and highest near the sources.

Large woody debris or rock outcrops projecting into the channel create form friction. As in the case of friction resistance, total hydraulic strain associated with form resistance increases towards the signal source. In contrast to bed friction (where water velocity decreases towards the friction source), water velocity increases towards the signal source for form resistance because of local reduction in conveyance area and increased travel distance of water flowing around an obstruction. A fish approaching a stump from the upstream direction will sense an increase in total hydraulic strain and an increase in water velocity until solid boundary effects very close to the obstruction are encountered. By integrating information between the total hydraulic strain and velocity fields, fish have sufficient information to separate channel structures associated with friction or form resistance, thereby creating a hydrodynamic 'image' of their immediate surroundings of sufficient resolution to guide local swim path selection. Water is a relatively dense and incompressible fluid; therefore, pattern in the hydraulic near field (within several body lengths) will extrapolate to the hydraulic far field because of continuity of mass and momentum. The SVP Hypothesis explains how emigrants select swim paths that minimize migration time, bioenergetic cost, and exposure to predators or other time-dependent mortality sources.

To maintain neutral buoyancy, an emigrant alters the amount of gas in its swim bladder when it changes depth. The process is bio-energetically cheap, but slow (Strand et al., 2005). Therefore, the SVP Hypothesis characterizes the fish's ability to change depth as more generally related to its ability to adjust swim bladder volume than to its vertical swimming velocity. Those fishes that do not possess a swim bladder may not require consideration of pressure changes associated with changing depth, although other differences between physostomous and physoclistous fishes may need to be considered.

The SVP can be related both to basic fluvial geomorphology and fish mechanosensory system anatomy (Goodwin et al., 2006), suggesting that it is a general hypothesis explaining active downstream fish movement behavior.

\section{Cognitive modeling using agents}

We relate fish cognition and movement to hydrodynamic cues using agent-based modeling concepts described in detail in Goodwin et al. (2006) and briefly described below, to illustrate how agent-based modeling can generally be used to accurately simulate fish movement behavior. Executing the SVP Hypothesis as a behavioral rule requires four agents (i.e., mathematically tractable representation of animal perceptions as in Bian, 2003): default $\left(A_{0}\right)$ (absence of other agents), friction resistance $\left(A_{1}\right)$, form resistance $\left(A_{2}\right)$, and pressure gradient $\left(A_{3}\right)$. Fish perceive agents as events or threshold changes by their hydraulic signatures. The non-default agents are each uniquely identified by corresponding thresholds, $\mathrm{k}_{1}, \mathrm{k}_{2}$, and $\mathrm{k}_{3}$ defined as follows. The friction resistance agent is perceived when the total hydraulic strain threshold exceeds $k$, and the form friction agent is perceived when total hydraulic strain exceeds $k_{2}$, where $k_{2} \gg k_{1}$. The pressure gradient agent is perceived when change in hydrostatic pressure exceeds $k_{3}$.

We represent perceived stimulus strength of total hydraulic strain at the virtual fish centroid at time $t$ as the log of physical intensity using an analogy to the decibel scale for sound as

$$
I(t)=\log _{10}\left[S(t) / S_{0}\right]
$$

where the time varying physical intensity is $S(t)=\Sigma\left|\partial u_{\mathrm{i}} / \partial x_{\mathrm{j}}\right|$ and $S_{0}$ is a reference value. Mathematically, detection thresholds are expressed as:

$$
\frac{I(t)}{I_{\mathrm{a}}(t)}>k_{\mathrm{i}}
$$

where $I_{\mathrm{a}}$ is the acclimated total hydraulic strain level, and $k_{\mathrm{i}}$ is the threshold level associated with $A_{\mathrm{i}}$. We characterize the background level using an exponentially weighted moving average (EWMA):

$$
I_{\mathrm{a}}(t)=\left(1-m_{\text {strain }}\right) \cdot I(t)+m_{\text {strain }} \cdot I_{\mathrm{a}}(t-1)
$$

where $m_{\text {strain }}$ is an adaptation coefficient with a value between 0 and 1 that scales the rate of adaptation to new conditions.

We represent the emigrant's perception of depth change as a linear function of depth so that depth change detection occurs when the difference between depth, $d(t)$, and the acclimated depth, $d_{a}(t)$, exceeds $k_{3}$. Acclimated depth is defined by an EWMA with separate adaptation coefficient $m_{\text {depth }}$ for up and down movement:

$$
\begin{gathered}
d_{\mathrm{a}}(t)=\left(1-m_{\text {depth }}\right) \cdot d(t)+m_{\text {depth }} \cdot d_{\mathrm{a}}(t-1) \\
m_{\mathrm{depth}}= \begin{cases}C_{\mathrm{d}} \cdot m_{\mathrm{depth}} & \text { if } d(t)<d_{\mathrm{a}}(t) \\
m_{\mathrm{depth}} & \text { if } d(t) \geq d_{\mathrm{a}}(t)\end{cases}
\end{gathered}
$$

where $C_{\mathrm{d}}$ is a coefficient between 0 and 1 , acknowledging that filling of the swimbladder to descend is slower than emptying gases to ascend. 
The presence of an agent stimulus is treated as a Boolean event, $e_{\mathrm{i}}(t)$ (Anderson 2002) expressed as:

$$
e_{i}(t)=\left\{\begin{array}{lll}
0 & \text { if } & I(t) / I_{a}(t)<k_{i} \\
1 & \text { if } & I(t) / I_{a}(t) \geq k_{i}
\end{array}\right.
$$

Using a game theoretic framework (Anderson 2002), a virtual fish estimates the probability $\left(P_{\mathrm{i}}\right)$ of obtaining the intrinsic utility $\left(u_{\mathrm{i}}\right)$ of a behavior using information streams acquired by its sensory system. Behaviors have a bioenergetic cost $\left(C_{\mathrm{i}}\right)$ whether or not the utility is obtained, so that expected utility $\left(U_{\mathrm{i}}\right)$ from behavior $\left(B_{\mathrm{i}}\right)$ is:

$$
U_{\mathrm{i}}(t)=P_{\mathrm{i}}(t) \cdot u_{\mathrm{i}}-C_{\mathrm{i}}(t)
$$

In this framework, a virtual fish updates probabilities for each behavior at each time step and selects the behavior that has the greatest expected utility. The probability estimate at time $t$ depends on the estimate at $t-1$ and new information available between $t-1$ and $t$ summarized as an EWMA, so that probability of obtaining utility $u_{\mathrm{i}}$ is:

$$
P_{\mathrm{i}}(t)=\left(1-m_{\mathrm{i}}\right) \cdot e_{\mathrm{i}}(t)+m_{\mathrm{i}} \cdot P_{\mathrm{i}}(t-1)
$$

where $e_{\mathrm{i}}(t)$ is a Boolean event measure and $m_{\mathrm{i}}$ is a memory coefficient weighting current information against past information embodied in $P_{i}(t-1)$. Maintaining information across time through an EWMA produces persistence in behaviors (where fish behavior during time increment $t$ to $t+1$ depends on acclimatization to past conditions) an important feature in modeling animal movement (Wu et al., 2000; Benhamou, 2006).

The four agents described above $\left(A_{0}, A_{1}, A_{2}\right.$, and $\left.A_{3}\right)$ produce the following four behaviors, respectively: $\left(B_{0}\right)$ swimming with the flow vector, $\left(B_{1}\right)$ swimming towards increasing water velocity to minimize total hydraulic strain, $\left(B_{2}\right)$ swimming towards decreasing water velocity or against the flow vector to minimize total hydraulic strain, and $\left(B_{3}\right)$ swimming towards acclimated pressure (depth). Emigrant swimming speed is bounded between burst speed, 10 body lengths per second, and nominal cruising speed, $\sim 2$ body lengths per second (Beamish, 1978). In each time increment, fish orientation and speed are set by the threshold triggered behavior $B_{\mathrm{i}}$ plus a random component.

\section{Applying the NFS: CFD Model, Acoustic-Tag Telemetry, and Passage Data}

Hindcasting and forecasting require three sets of information that must be integrated to develop, test and apply the model: (1) Behavior data: highly resolved time- and spaceaccurate 3-D positions of individual fish movement in a relatively constant hydraulic field; (2) Passage data: accurate exit-specific passage information of target fish groups; and (3) CFD model data: detailed CFD model simulations that accurately describe flow field patterns associated with behavior and passage data. Behavior data is required for algorithm development, passage data is required for model calibration and validation, and CFD model data is required for both cali- bration/validation and forecasting. Furthermore, CFD model data must be correctly synchronized with behavior and passage data to ensure that prototype biological information is correctly matched to project operation. Errors and uncertainties in any one of the information sets affect the accuracy of the NFS.

NFS algorithms and SVP Hypothesis were developed and calibrated using acoustic-tag telemetry and passage data from a single structural/operational configuration at Lower Granite Dam, Snake River, USA (Goodwin et al., 2006). The NFS was then validated against 23 different structural/operational configurations at the following USA dams: The Dalles (Columbia River), Lower Granite (mid Snake River), Wanapum (mid Columbia River), and Ice Harbor (lower Snake River) Dams (Goodwin et al., 2007).

\section{Results}

We evaluated NFS performance for North American emigrants using four separate metrics described below:

\section{Metric 1: Can the NFS explain trends in measured passage at multiple dams?}

Yes, linear regression of measured versus forecasted passage shows the NFS successfully hindcasts passage for 23 configurations (Fig. 1). Mean slopes/r-squares from this new evaluation are $0.90 / 0.82,0.78 / 0.80$, and $0.67 / 0.43$ for bypass, spillway, and powerhouse turbine passage routes, respectively (Goodwin et al., 2007). R-square values above about 0.65 are considered useful for decision-making (Prairie, 1996).

\section{Metric 2: Are NFS forecasts substantially better than pas- sive particles?}

Yes, all NFS forecasts with the behavior rules "turned off” (virtual fish moving as passive particles, e.g., Fig. 2B result in passage forecasts substantially less than the r-square threshold of 0.65 (Fig. 1B). In comparison, almost all "rules on" forecasts (e.g., Fig. 2a) produce r-squares above the threshold (Fig. 1a).

\section{Metric 3: Can the NFS rank alternatives by passage perfor- mance?}

Yes, NFS forecasts generally match measured rankings of configurations as top-, moderate-, and low-performing using the metric of passage per unit of CFD modeled flow for bypass, spillway and powerhouse turbines (Goodwin et al., 2006). Mismatches are likely largely influenced by errors in measured passage efficiency and poor project synchronization. Rankings based on passive particles are poor.

\section{Metric 4: Do NFS virtual fish tracks match/explain tracks of individually-tagged fish?}

Yes, the NFS successfully duplicates the pattern of real fish following the trash boom (Figs.3b-c and Fig.4) without visual cues by integrating information between the total hydraulic strain and velocity fields (Fig. 5). At $t=2120 \mathrm{sec}$, the 


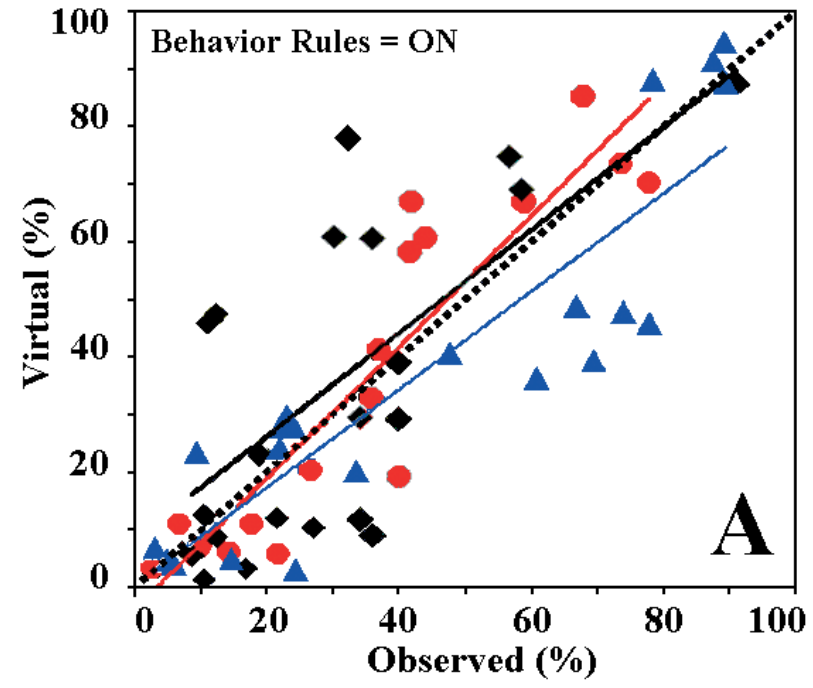

Bypass _ Linear Best Fit (Bypass)

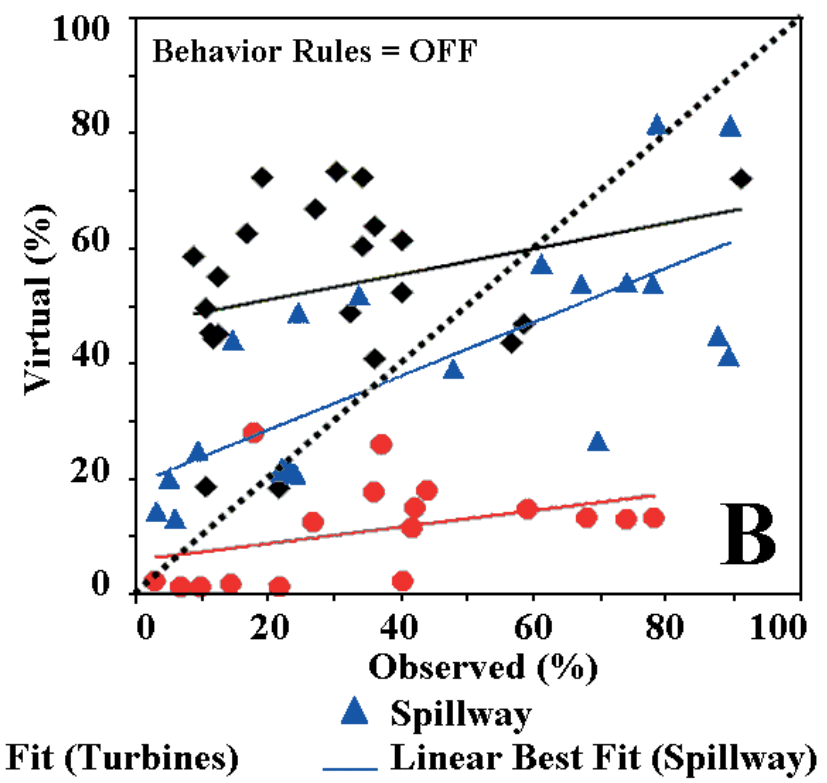

Fig. 1. Comparison of observed and NFS predicted (based on 5,000 virtual fish) emigrant passage proportions for 23 configurations for behavior rules turned on (A) and behavior rules turned off (B) (virtual emigrants act as passive particles). Passage (exit) routes are bypass, spillway and turbines. Routes with either $0 \%$ or $100 \%$ of river flow in CFD model are not plotted or factored into trend lines. Sources of observed data are described in Goodwin et al. (2006).

virtual emigrant approaching the Lower Granite Dam trash boom perceives total hydraulic strain exceeding threshold $k_{1}$, thereby identifying the environmental agent as friction resistance $\left(A_{1}\right)$ (Fig. 3c, strain plot). Agent identification triggers a sequence of events, $e_{1}(t)$, increasing the expected utility $U_{1}$ (the motivational value of response $B_{1}$ to stimulus agent $A_{1}$ ). A short time later $U_{1}$ exceeds utility $U_{0}$ (the motivational value of the default behavior $B_{0}$ ). Only when $U_{1}$ exceeds $U_{0}$ (Fig. 3c, $t=2128 \mathrm{sec}$ ) does the behavior switch from $B_{0}$ to $B_{1}$. The delay between stimulus identification and observed response is the 'response latency,' an important feature of fish behavior (Webb, 2004).

\section{Discussion}

\section{Use of NFS from North American migratory fishes}

Before the use of the NFS, fish guidance and bypass structure designs were based on hydraulic information from physical and computational models, general patterns of fish passage derived from statistical analyses, and the experience and judgment of engineers and biologists. The NFS is designed to supplement these approaches by adding two unique new capabilities to guidance and bypass efficiency forecasting. First, the NFS uses velocity and distortion field information (approximated using "total hydraulic strain") to characterize the hydrodynamic cues used by emigrants. Second, the NFS realistically simulates how fish experience and respond to the hydraulic regime by using response latencies and adaptive behaviors known to be important by animal behavioral researchers. The SVP Hypothesis that underlies fish responses in the NFS indicates that regional bypass design criteria based on average hydraulic conditions and ve- locities will be ineffective. Emigrants respond and adapt to hydraulic gradients, not absolute velocities. Thus, systems designed on average conditions cannot address emigrant experience and resulting adaptation to the environment. The NFS serves as "corporate memory" of fish passage knowledge. As findings become available, they can be integrated within the NFS for regional use.

The distortion field is considerably easier to affect than bulk flow patterns, and our research indicates that relatively small structures such as trash booms can substantially affect fish movement behavior by affecting the distortion field. This key finding can help identify innovative new guidance and bypass technologies that take advantage of flow field distortion to adjust emigrant spatial distribution.

\section{Considerations for applying the NFS in large South Ameri- can rivers}

The ability of the NFS to link basic principles of geomorphology, fluid dynamics, and fish sensory system capabilities to emigrant behavioral response suggests that it also has promise for application to South American fishes. It seems a plausible assumption that the same interplay of factors also affects the behavior of South American fishes and that, in turn, these factors must be considered in fish passage system design.

Successful application of the NFS model in South America requires: 1) an accurate, high-resolution description of hydrodynamic patterns near target dams or targeted reaches of the river; 2) knowledge of how individual fish respond to hydrodynamic and other cues; and 3) an understanding of the life-history strategies employed by fishes in South America. Each of these requirements is discussed below. 

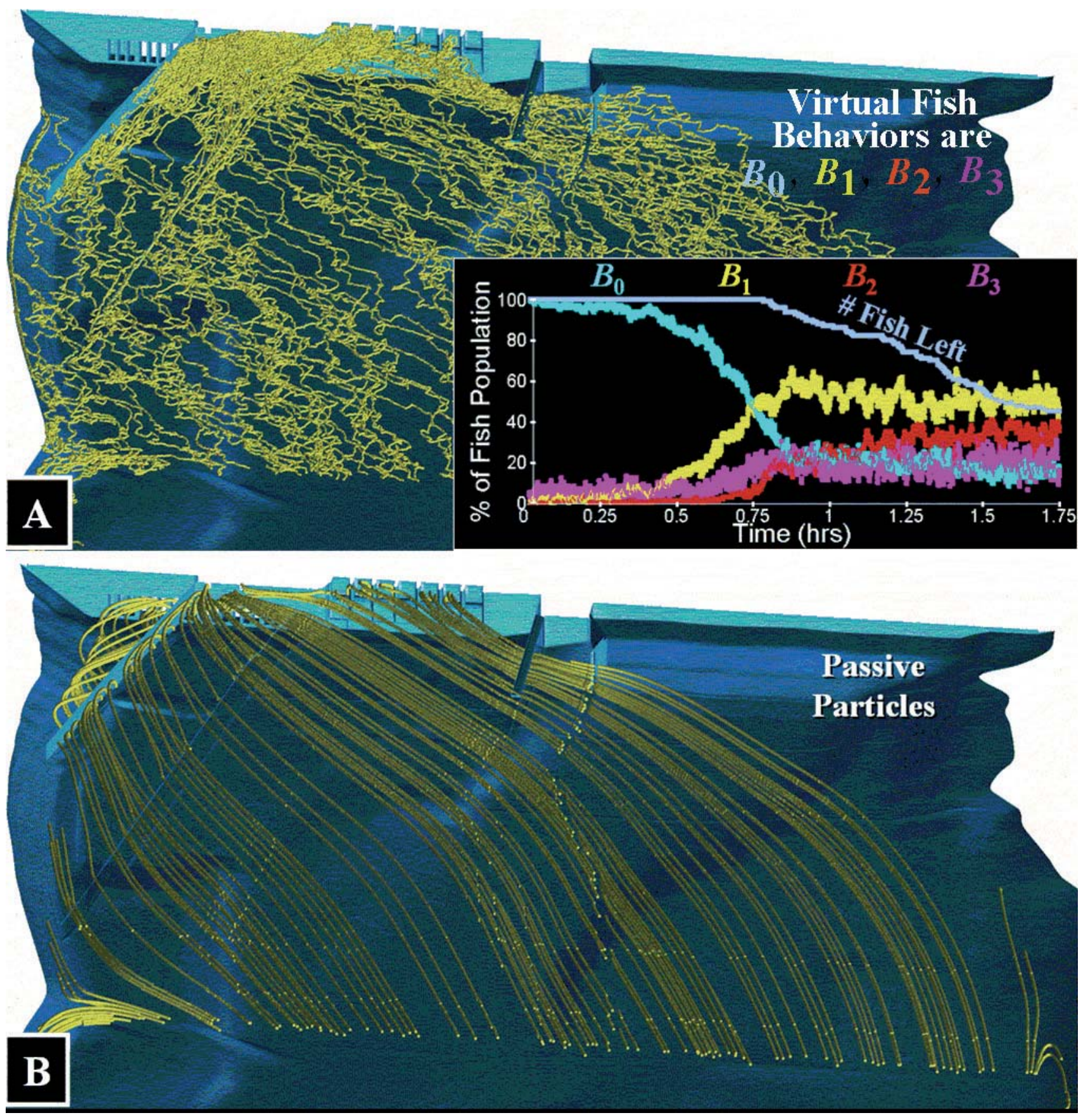

Fig. 2. Comparison of movement of 100 NFS virtual emigrants $[A]$ and 100 passive particles [B] released $700 \mathrm{~m}$ upstream of Lower Granite Dam. Virtual emigrant and particle tracks are yellow. Note the pattern of behavior changes as the virtual fish approach the dam (inset plot in [A]). Upstream of the dam, the default behavior $B_{0}$ dominates, but the other behaviors become more dominant as the hydrodynamic environment becomes more complex near the dam (inset to $[\mathrm{A}]$ ).

We anticipate that hydrodynamic conditions in the tailraces of different South American dams will vary substantially by dam design and region. However, CFD modeling is sufficiently advanced that even the most challenging of downstream sites can be adequately simulated using state-of-theart CFD modeling, including complex bedforms and braided channels. As noted by Goodwin et al. (2006), the cues and the threshold of response may vary for different-sized emigrants or different species because of slight differences in sensory system architecture and behavior. In North America, juvenile emigrant behavior near dams appears dominated by hydrodynamic variables. This assumption that fish select their swim path predominantly by hydrodynamic cues, if met in South America, will allow the NFS to be applied to conserve South American fishes by simply adjusting algorithm coefficients based on descriptions of observed behavior. However, this assumption may not be supported in South America. For example, migration by South American fishes may be 


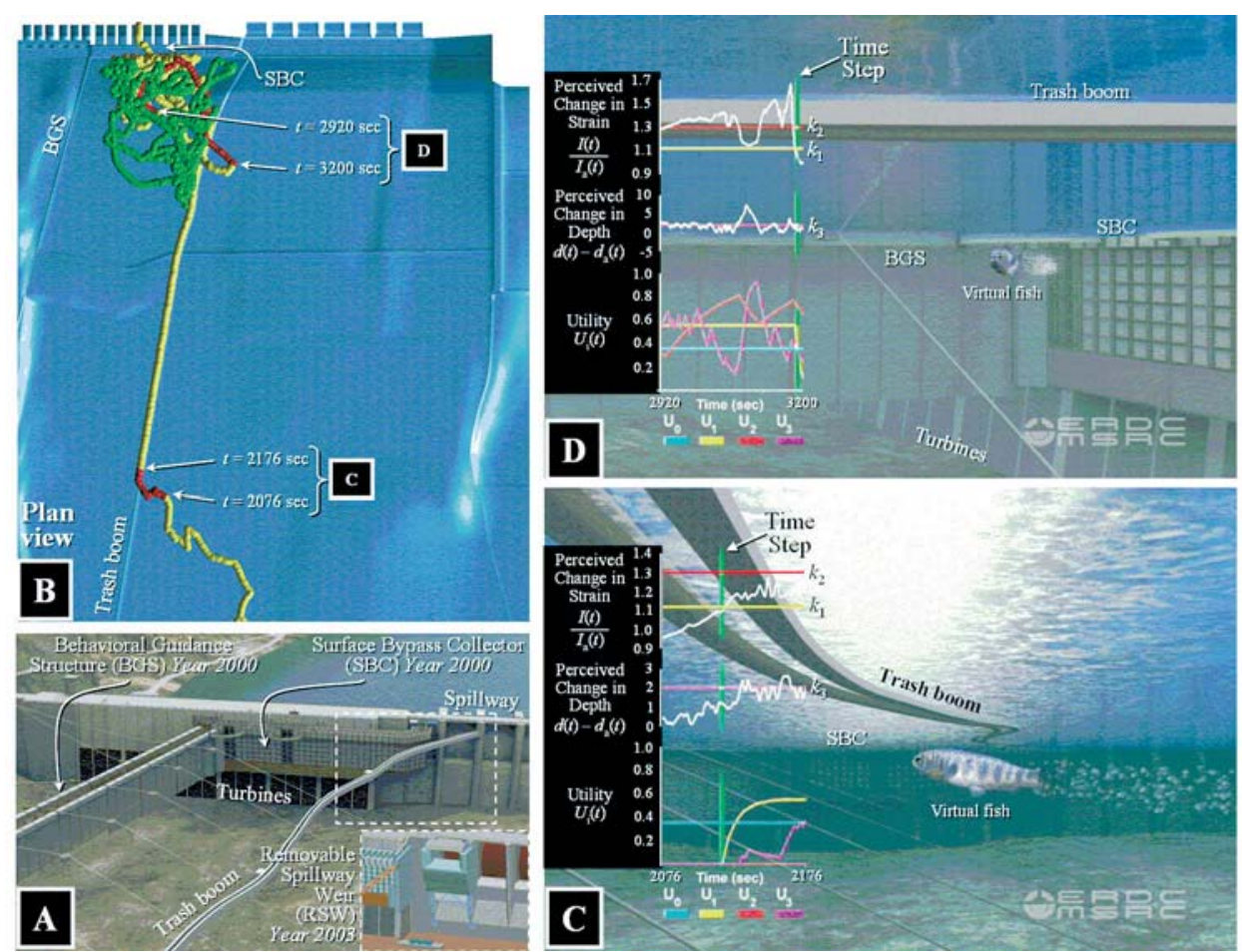

Fig. 3. Project features at Lower Granite Dam on the Snake River, WA USA for 2000 and 2003 studies [A]. The Behavioral Guidance Structure (BGS) is intended to guide emigrants to the Surface Bypass Collector (SBC) and occlude them from the 3 turbine intakes nearest the shore. In 2003, a Removable Spillway Weir (RSW) was deployed in the spillbay nearest the powerhouse in lieu of the SBC; the BGS was also removed. Acoustic-tag emigrant track (green in [B]) provided by U.S. Geological Survey (Cash et al., 2002). CFD model depiction of forebay hydrodynamic pattern for [B], [C] and [D] in Fig. $5 \mathrm{a}$.

guided by sound, magnetic field lines, odor, or other stimuli, singly or in combination. NFS algorithms would have to be modified to reflect the behavior of South American target species if they vary significantly from North American species. Modification of algorithms within the behavior component of the NFS is relatively simple compared to the complex and difficult task of coupling the algorithms to CFD output.

Upstream fish passage technologies are well developed for a few anadromous species including salmonids (e.g., Atlantic and Pacific salmon, sea-run trout) and clupeids (e.g., American and Allis shad, alewives, blueback herring) in North America and Europe (Larinier, 2001). In South American rivers, most fish passage systems have been either poorly evaluated or never evaluated. However, some general information to guide fish passage design and operation can be inferred from general, ecological attributes of South American migratory fishes (primarily Siluriforms and Characiforms). The largest Siluriforms, the giant catfishes, are migratory and have significant socio-economic importance. Some Siluriforms, such as Pseudoplatystoma fasciatum and P. corruscans and Zungaro jahu can exceed 1-meter in length and weigh more than $60 \mathrm{~kg}$. Some of the giant catfishes are common in many South American basins where most of them have been designated as threatened species. Large migratory Characiforms do not exceed $25 \mathrm{~kg}$ and include many species of recreational value.

The general, life-history patterns of South American migratory fishes are well known and have been reviewed by many authors (see Carolsfeld et al,. 2004). They are generally potadromous (migrate within the river corridor) and iteroparous (reproduce multiple times during their life times). During each reproductive cycle, adults typically migrate upstream in response to temperature and flow cues to established spawning sites and then, after spawning, migrate back downstream to adult habitats where they feed to regain the condition necessary for the next year's spawning migration (e.g. Petrere, 1985; Oldani, 1990; Bonetto, 1986). Eggs and larvae drift passively and disperse into floodplains where they rear until they also reach adult downstream habitat (Nakatani et al., 1997). It is unknown if adult and larval downstream movements are synchronized. Of critical importance, iteroparity requires both upstream and downstream passage at dams over an extended time period.

Within this broad characterization, migratory fishes of South America exhibit different spatial and temporal migration patterns depending on the species and river segments within which they occur (Petrere, 1985). Some fish populations may even migrate among large rivers as was noted in the lower De la Plata River basin (Espinach Ross et al., 1998). Prochilodus lineatus performs both short $(150 \mathrm{~km})$ and long $(1500 \mathrm{~km})$ migrations within the same river (Bonetto, 1986, 1981, Sverlij et al., 1993). In the Paraná River this species starts migrating upstream as water level rises in the late spring and water temperatures reach 23 to $24{ }^{\circ} \mathrm{C}$ (Nakatani et al., 2001; Oldani \& Baigún, 2006), but in the Pilcomayo River, an 


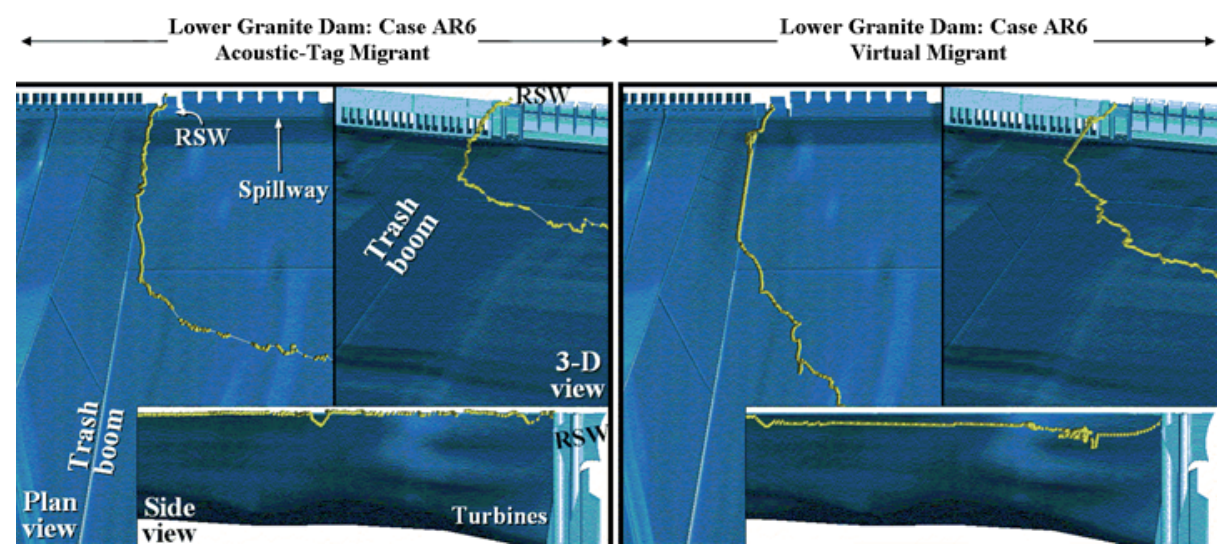

Fig. 4. Comparison of 3-D tagged (left) and virtual (right) emigrant tracks for Lower Granite Dam 2003 RSW. Dam operation described in Goodwin et al. (2006). CFD model depiction of forebay hydrodynamic pattern in Fig. 5. Acoustic-tag emigrant track provided by U.S. Geological Survey (Cash et al., 2005).

important tributary of the Paraguay River, upstream migrations occur in the fall as flow recedes. In the Amazon basin migratory movements are even more complex because fish move upstream and downstream during the same season depending on the river area (Goulding, 1980).

Some information is available that offers clues on how South American fishes select their swim path through the complex flow fields of rivers. This information is critical because it can be used to help evaluate the adequacy of the hydrodynamically-based behavior algorithms within the NFS. Telemetry and acoustic surveys performed in the Paraná River show that some migrating fishes are associated with the thalweg (Oldani et al., 1992, Oldani et al., 2002, Poddubnyi et al., 1981). Poddubnyi et al. (1981) identified several habitats in the Middle Paraná used by migratory species such as littoral or resting areas, deep pools and thalweg dune areas. They determined that species such as P. lineatus, Salminus brasiliensis, Luciopimelodus pati and Leporinus obtusidens, selected water velocity gradients (strain) and channel bathymetry as a source of information during their upstream movements. In the Uruguay River, Delfino et al. (1986) noted that P. lineatus and L. obtusidens used the side slope of the channel to guide swim path selection towards Salto Grande Dam, whereas S. brasiliensis and $P$. corruscans occurred in turbulent zones of the channel. Downstream of Yacyretá Dam, Oldani et al. (2001) showed that fish used deep areas with low water velocity as migratory routes.

The little information available from South America, summarized above, suggests that fishes use either hydrodynamic or bedform variables to select their swim path during migration. While not conclusive, this information suggests that the general form of the algorithms within the NFS should, with some adjustment, be used to analyze and forecast swim path selection for South American fishes.

The next step in the application of the NFS to conserve South American fishes is the collection of tracking information of the appropriate scale and resolution to understand and forecast fish 3-D movements. This tracking information can be acquired by using tracking technology such as acous- tic tags, radio tags, and multibeam sonar. Detailed tracks made by observed fish are translated to the geospatial referencing system used by the CFD model. The NFS is then used to project hydraulic data from the CFD output to the fish's location and at user-defined distances around the fish to create a comprehensive data set describing the hydraulic environment and bedform near the fish at discrete time steps. If the time steps are sufficiently small (1-3 seconds), the NFS can be used to calculate fish swimming speed and bearing relative to flow field velocity vectors. The resulting data set can be analyzed graphically and statistically to develop hypotheses explaining fish migration behavior. The hypotheses can be codified as movement algorithms and evaluated within the NFS used in predictive mode. Movement hypotheses can be tested and refined until a working model is developed that can be used to evaluate fish passage designs.

The approaches described above can be used to understand and forecast how fish respond to hydrodynamic and bedform patterns in critical areas such as the tailraces, fish passage entrances and exits, spillways, and turbine areas. In many cases, information that can be used to develop a South American NFS may already be available. For example, Oldani and Baigún (2002) at Yacyretá Dam studied daily movements of the primary migratory species and noted that Brycon orbignyanus, Leporinus acutidens and P. lineatus exhibited diurnal movements. Other species such as Iheringichthys labrosus, Zungaro jahu, Rhinelepis aspera, Rhinodoras dorbignyi and Rhaphiodon vulpinus were categorized as dusk-active species whereas Sorubim lima, Piaractus mesopotamicus and S. brasiliensis were classified as sunrise-active species. However, most species were active nocturnally including Hemisorubim platyrhynchos, Megalonema platanum, Oxydoras kneri, Pterodoras granulosus and Schizodon borellii. Time preferences were not noted for $L$. obtusidens, P. corruscans and Schizodon platae.)

In addition to fine- and coarse-scale behavior, fish swimming capability data are also important for designing and locating passage systems. Fish swimming speeds are usually 


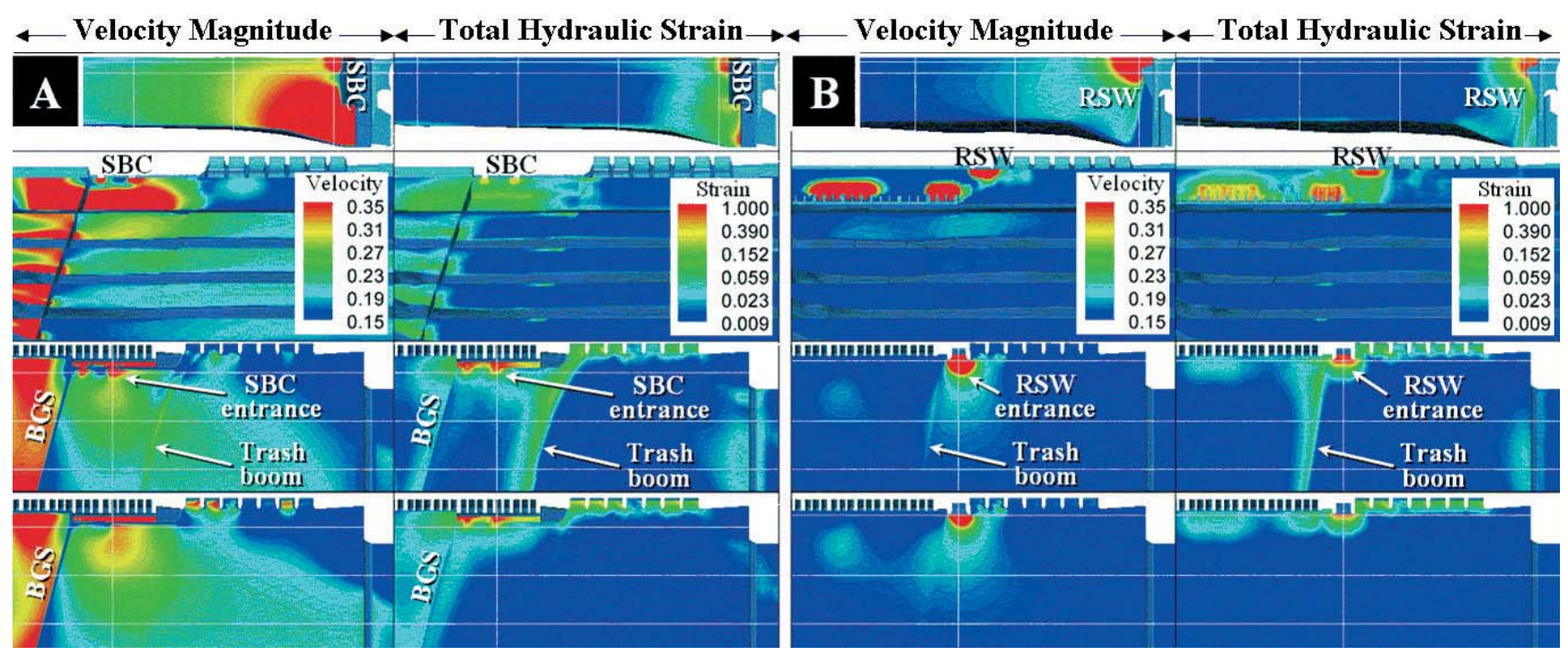

Fig. 5. Patterns in velocity magnitude $(\mathrm{m} / \mathrm{s})$ and total hydraulic strain $\left(\mathrm{s}^{-1}\right)$ for the Lower Granite Dam SBC in $2000[\mathrm{~A}]$ and RSW in 2003 [B]. Dam operations described in Goodwin et al. (2006). Each of the two configurations is described with 4 paired velocity magnitude and total hydraulic strain plots. For each grouping, top plots depict a cross-section through the bypass structure (middle entrance of SBC in 2000 and RSW in 2003), 3-D plots in each grouping are cross-sections parallel to dam face at $50 \mathrm{~m}$ intervals, and the two bottom plots are horizontal plan views $(\mathrm{z}=37$ and $42.25 \mathrm{~m})$ showing the change in hydrodynamic pattern at different locations and depths.

categorized as sustained, prolonged or burst (Hoar \& Randall, 1987). While the speeds associated with each of these swimming categories are available for many North American and European species (e.g., Bell, 1991), they are not yet generally available for South American fishes. Indirect information on swimming speed is available for some South American fish species as well as anecdotal information on how specific species avoid certain design features. Based on tagging experiments, $S$. brasiliensis and $P$. lineatus in the Paraná River migrate between 5 and $17 \mathrm{~km} /$ day (Poddubnyi et al., 1981). Similarly, in the Uruguay River, S. brasiliensis were observed to migrate up to $17 \mathrm{~km} /$ day during upstream migration (Delfino \& Baigún, 1985), but were reluctant to enter collection channels in Santo Grande Dam. Similar responses could be expected from large catfishes which almost never enter the fish elevators at this dam.

Fish swimming speed is directly related to fish length and water temperature (Wardle, 1975). South American migratory fish are often large in size and, therefore, may be capable of rapid swimming speed. For example, Godoy (1985) recovered tagged fishes (P. lineatus, S. brasiliensis and L. obtusidens) in Urubupungá Falls and below Ilha Solteria in the Paraná River that must have ascended spillway currents up to $13 \mathrm{~m} /$ s. This author found in Cachoeira Dourada on the Paranaíba River tagged $P$. lineatus that must have passed spillway currents of $12-15 \mathrm{~m} / \mathrm{s}$. Similarly, this author found tagged fishes of this species in the Cachoeira de Emas on the Mogi Guassu River which must have passed through spillway water velocities of $12 \mathrm{~m} / \mathrm{s}$. In all cases, it is unclear if lower water velocities could have occurred where the spillway gates seal against the spillbay walls.
Nestler et al. (in press) emphasize that the hydrodynamic cues used by juvenile salmon during emigration reflect the dynamic balance between flow field pattern and bedform. That is, emigrants are able to create a "hydrodynamic snapshot" of the flow field pattern within range of their sensory system and then evolved movement behaviors based on a consistent relationship between the near-field pattern and the farfield pattern. Unfortunately, dams are geologically recent structures in which the shape of features is not related to a dynamic balance with the flow field As a consequence, fish behaviors that evolved over long periods of time in natural aquatic settings may not work at dams. It may be relatively easy for migrating fish to become confused at dams because the hydrodynamic cues used to navigate through complex follow fields may be of limited value near dams. This breakdown in the usefulness of hydrodynamic cues at dams may explain why migrants concentrate in the tailrace at some distance from powerhouses, as was noted at both Salto Grande and Yacyretá dams.

There may be additional factors that must be considered to develop passage systems for South American Characiforms and Siluriforms. First, they are hearing specialists because they have a Weberian apparatus comprised of a complex series of bones, muscles and ligaments that connect the inner ear to the swim bladder. This allows the swim bladder to be used as a sensitive sensor of acoustic signals in the aquatic environment. It is, therefore, reasonable to assume that sound may also play a role in migration behavior for South American fish species possessing the Weberian apparatus. Second, fish fall into two broad anatomical categories for regulating gas volume within their swim bladder: physostomous (swim 
bladder connected to pharynx) and physoclistous (swim bladder not connected to the pharynx). By regulating gas volume within the swim bladder, fish are able to adjust their buoyancy. Salmonids and Siluriforms are physostomous and therefore can rapidly adjust their buoyancy by "burping" air or gulping air in when they are near the surface. Characiforms are physoclistous and can only adjust swim bladder volume slowly by gas exchange with blood in the circulatory system using a gas gland.

We conclude that the basic form of the algorithms used in the NFS will likely extend to South American fishes, because direct and indirect evidence suggests that they select their swim path primarily using hydrodynamic cues or bedform shape. However, the coefficients that adjust the algorithms must be determined by studies conducted specifically on South American fishes. Species-specific NFS versions are possible as long as the many lessons learned from the initial NFS application are followed. First, measured fish position data must be accurate in time and space, or alternatively, the error in each axis must be consistent and described. Second, project operation must be constant during the conduct of fish movement data so that the hydraulic field experienced by tagged fish can be accurately simulated by the CFD model. Third, the CFD must exhibit continuity in both the primary field (velocity magnitude) and in the derivative field (strain field). Typically, CFD meshes must contain about a million or more nodes with more nodes concentrated near the dam where both spatial and flow field features are intense and small. Discontinuities in the primary or secondary field from the CFD model will produce spurious behaviors of virtual fish and cause NFS results to be inaccurate. Complete recommendations for CFD modeling to support fish bypass studies can be found in Weber et al. (2006).

If the constraints and standards described above are met, then the NFS should be amenable to application in conserving South American fishes if appropriate individual fish position traces and summary passage data are available. Application of the NFS to South American fish conservation offers the following economies. First, the extensive development costs $(\sim \$ 1.0 \mathrm{M})$ of constructing the NFS computational infrastructure will not be required. Second, the research to identify and codify general behavioral algorithms that can simulate response latency and memory, two high-level cognitive processes of known importance to animal behavior scientists, will not have to be duplicated. Third, the existing link between fluvial geomorphology, fluid dynamics, and fish behavior uncovered by NFS application may extend as a general strategy to any fish that must move across large spatial scales in a bioenergetically efficient manner. Fourth, advanced CFD modeling capability is available in South America so that regional hydrodynamicists can support fish passage studies. Thus, the present structure of the NFS affords an excellent beginning point from which to approach South American fish passage challenges.

Finally, we emphasize that in South America, dams should provide adult fish passage in both upstream and downstream directions. Unlike the case of North American dams, South American dams lack bypass structures or channels to allow downstream migrations and fish must pass either through turbines or spillways or remain in the reservoirs. The studies conducted to develop the NFS led to the development of the SVP Hypothesis as an explanation of how emigrants systematically hydro-navigate through complex flow fields. Similar studies in South America may identify other strategies that integrate hydrodynamics, geomorphology and behavior. Inadequate understanding of the cues used by fish to hydronavigate leads to failed fish passage designs and is one explanation why most fish passage systems in large South American rivers have failed to pass sufficient numbers of fishes to sustain target populations. River regulation impacts other than inadequate fish passage may also deplete migratory fishes. We urge researchers in South America to systematically collect the fish distribution and behavior data to parameterize a tool such as the NFS that can be used to analyze fish behavior, to forecast the performance of alternative passage systems during planning, and to serve as the repository of knowledge about fish passage dynamics.

\section{Literature Cited}

Anderson, J. J. 1988. Diverting migrating fish past turbines. The Northwest Environmental Journal, 4:109-128.

Anderson, J. J. 2002. An agent-based event driven foraging model. Natural Resource Modeling, 15(1):55-82.

Beamish, F. W. H. 1978. Fish Physiology Volume VII "Locomotion". Pp 101-183. In: Hoar, W. S \& D. J. Randall (Eds.). Academic Press, New York, NY, 576p.

Bell, M. C. 1991. Fisheries handbook of engineering requirements and biological criteria. Fish Passage Development and Evaluation Program, U.S. Army Corps of Engineers, Sacramento District.

Benhamou, S. 2006. Detecting an orientation component in animal paths when the preferred direction is individual-dependent. Ecology, 87(2): 518-528.

Bian, L. 2003. The representation of the environment in the context of individual-based modeling. Ecological Modelling, 159:279-296.

Bonetto, A. A. 1986. Fish of the Paraná System. The ecology of River System. Pp. 340-386. In: Davies, B.R. \& K.F. Walker (Eds.), Dordrecht, The Netherlands, 574p.

Bonetto, A. A., M. Canon Veron \& D. Roldan. 1981. Nuevos aportes al conocimiento de las migraciones de peces en el río Paraná. Ecosur, 8:29-40.

Carolsfeld, J., B. Harvey, C. Ross \& A. Baer. 2004. A migratory fishes of South America: biology, fisheries, and conservation status. Victoria: World Fisheries Trust/IDRC/World Bank, 372p.

Cash, K. M., N. S. Adams, T. W. Hatton, E. C. Jones, \& D. W. Rondorf. 2002. Three-dimensional fish tracking to evaluate the operation of the Lower Granite surface bypass collector and behavioral guidance structure during 2000. Final Report prepared by the U.S. Geological Survey Columbia River Research Laboratory for the U.S. Army Corps of Engineers, Walla Walla District, Walla Walla, WA, 73p.

Cash, K. M., T. W. Hatton, E. C. Jones, R. J. Magie, N. S. Adams \& D. W. Rondorf. 2005. Three-dimensional fish tracking to 
evaluate the removable spillway weir at Lower Granite Dam during 2003. Final Report prepared by the U.S. Geological Survey Columbia River Research Laboratory for the U.S. Army Corps of Engineers, Walla Walla District, Walla Walla, WA, $102 p$.

Coutant, C. C. 2001. Integrated, multi-sensory, behavioral guidance systems for fish diversions. Pp 105-113. In: C. C. Coutant (Ed.). Behavioral technologies for fish guidance, American Fisheries Society, Bethesda, MD, 26, 193 p.

Coutant, C. C. \& R. R. Whitney. 2000. Fish behavior in relation to passage through hydropower turbines: a review. Transactions of the American Fisheries Society, 129: 351-380.

Espinach Ross, A., S. Sverlij, F. Amestoy \& M. Spinetti. 1998. Migration pattern of the sábalo Prochilodus lineatus (Pisces, Prochilodontidae) tagged in the lower Uruguay river. Verh. Internat. Verein. Limnol., 26: 2234-2236.

Godoy, M. P. 1985. Aquicultura: Atividades multidiscipinares. Escadas e outras facilidades para passagens de peixes. Estações de piscicultura. Florianópolis, Brasil, Eletrosul. 77p.

Goodwin, R. A., J. M. Nestler, J. J. Anderson, L. J. Weber, \& D. P. Loucks. 2006. Forecasting 3-D fish movement behavior using a Eulerian-Lagrangian-agent method (ELAM). Ecological Modelling, 192: 197-223.

Goodwin, R. A., J. M. Nestler, J. J. Anderson, D. L. Smith, D. Tillman, T. Toney, L. J. Weber, S. Li, J.-R. Cheng \& R. M. Hunter. 2007. The Numerical Fish Surrogate ${ }^{\mathrm{TM}}$ : A New Tool using Cognitive Ecology, Particle-Tracking, \& Hydraulic/Water Quality Modeling to Convert Observed Patterns in Fish Movement and Passage to a Mechanistic Hypothesis of Behavior for Management Design Support. Draft Final Technical Report ERDC/EL-07, U.S. Army Engineer Research and Development Center, Vicksburg, MS.

Goulding, M. 1980. The fishes and the forest. Explorations in Amazonian natural history. Berkeley, Los Angeles, University of California Press, 280p.

Hudspeth, A. J. 1989. How the ear's works work. Nature, 341:397404.

Kalmijn, A. J. 1989. Functional evolution of lateral line and inner-ear sensory systems. Pp 187-215. In: Coombs, S., P. Görner, \& H. Münz (Eds.). The Mechanosensory Lateral Line: Neurobiology and Evolution, Springer-Verlag, New York, NY, 724p.

Larinier, M. 2001. Environmental issues, dams and fish migrations. Pp: 45-90. In: G. Marmulla (Ed.) Dams, fish and fisheries. Opportunities, challenges and conflict resolution. FAO Fisheries Technical Paper Nro 419, 166p.

Montgomery, J. C., A. G. Carton, R. Voigt, C. F. Baker \& C. Diebel. 2000. Sensory processing of water currents by fishes. Philosophical Transactions of The Royal Society of London series B, 355(1401): 1325-1327.

Nakatani, K., A. A. Agostinho, G. Baumgartner, A. Bieletzki, P. V. Sanches, M. C. Makrakis \& C. S. Pavanelli. 2001. Ovos e larvas de peixes de água doce: desenvolvimento e manual de identifição. Maringá, EDUEM, 378p.

Nakatani, K., G. Baumgartner \& M. Cavichioli. 1997. Ecologia de ovos e larvas de peixes. Pp. 281-306. In: A. E. de Moraes Vazzoler, A. A. Agostinho \& N. Hahn (Eds.).A planicie de inundaçãodo Alto Rio Paraná, Maringá, EDUEM, 317p.

Nestler, J. M., R. A. Goodwin, D. Smith \& J. J. Anderson. (in press). A mathematical and conceptual framework for ecohydraulics. In: P. Wood P.J., D.M. Hannah \&J. P. Sadler (Eds.).Hydroecology and Ecohydrology: Past,Present, and Future, 2007, John Wiley \& Sons, Ltda.
Oldani, N. O. 1990. Variaciones de la abundancia de peces del valle del río Paraná. Revue D’Hydrobiologíe tropicale, 23(1):67-76.

Oldani, N. O. \& C. Baigún. 2002. Performance of a fishway system in a major South American dam on the Paraná River (ArgentinaParaguay). River Research and Application, 18:171-183.

Oldani, N.O., C. Baigún \& R. Delfino. 2005. Consideraciones sobre los sistemas de transferencia para peces en las represas de los grandes ríos de la cuenca del Plata en la Argentina. Pp. 367-383. In: F. G. Aceñolaza (coordinador). Temas de la Biodiversidad del Litoral fluvial argentino II. INSUGEO, Misceláneas, 14, Universidad de Tucumán, 550p.

Oldani, N. O., J. M. Iwaszkiw, O. H. Padin \& A. Otaegui. 1992. Fluctuaciones de la abundancia de peces del Alto Paraná (Corrientes, Argentina). Publicación Comisión Administradora del Río Ururguay, Serie Técnico-Científica, 1:43-55.

Oldani, N., P. Minotti, R. Rodriguez, R. Delfino \& C. Baigun. 2001. Incidencia de factores ambientales en la abundancia y distribución de peces del río Paraná y su relación con los sistemas de transferencia de la represa de Yacyretá. Natura Neotropicalis, 32(1):41-48.

Petrere Jr., M. 1985. Migraciones de peces de agua dulces en América Latina: algunos comentarios. COPESCAL Documento Ocasional $1.17 p$.

Poddubnyi, A. G., A. Espinach Ros \& N. Oldani. 1981. Recursos icticos del Paraná Medio en relación con la construcción de obras hidráulicas. (Memorias y recomendaciones). Informe Técnico Agua Energía Gerencia Estudios y proyectos Paraná Medio, Santa Fe (Argentina), 105p.

Prairie, Y. T. 1996. Evaluating the predictive power of regression models. Canadian Journal of Fisheries and Aquatic Sciences, 53:490-492.

Strand, E., C. Jørgensen \& G. Huse. 2005. Modelling buoyancy regulation in fishes with swimbladders: bioenergetics and behaviour. Ecological Modelling, 185: 309-327.

Sverlij, S. B., A. Espinach Ros \& G. Orti. 1993. Sinopsis de los datos biológicos y pesqueros del sábalo Prochilodus lineatus (Valenciennes, 1847). FAO, Sinopsis sobre la pesca $\mathrm{N}^{\circ} 154$, $64 \mathrm{p}$.

Voigt, R., A. G. Carton \& J. C. Montgomery. 2000. Responses of anterior lateral line afferent neurons to water flow. Journal of Experimental Biology, 203: 2495-2502.

Wardle, C. C. 1975. Limit of fish swimming speed. Nature, 255: 725-727.

Webb, P. W. 2004. Response latencies to postural disturbances in three species of teleostean fishes. Journal of Experimental Biology, 207:955-961.

Weber, L. J., R. A. Goodwin, S. Li, J. M. Nestler \& J. J. Anderson. 2006. Application of an Eulerian-Lagrangian-Agent method (ELAM) to rank alternative designs of a juvenile fish passage facility. Journal of Hydroinformatics, 8(4):271-295.

Workman, R. D., D. B. Hayes \& T. G. Coon. 2002. A model of steelhead movement in relation to water temperature in two Lake Michigan tributaries. Transactions of the American Fisheries Society, 131:463-475.

Wu, H., B. L. Li, T. A. Springer \& W. H. Neill. 2000. Modelling animal movement as a persistent random walk in two dimensions: expected magnitude of net displacement. Ecological Modelling, 132:115-124.

Received January 2007 Accepted June 2007 